УДК 373.3.[016:51]:004

DOI:

Ніна Руденко, кандидат педагогічних наук, старший викладач кафедри початкової освіти, Київсккого університету імені Бориса Грінченка Яна Гужик, студентка другого (магістерського) освітнього рівня Київського університету імені Бориса Грінченка Денис Широков, студент другого (магістерського) освітнього рівня Київського університету імені Бориса Грінченка

\title{
ОРГАНІЗАЦІЙНО-МЕТОДИЧНІ ОСНОВИ ЗАСТОСУВАННЯ ОСВІТНЬОЇ СТРАТЕГІЇ “ДЕРЕВО РІШЕНЬ” НА УРОКАХ МАТЕМАТИКИ В ПОЧАТКОВІЙ ШКОЛІ
}

У статті подано визначення основних дефініцій: початкова освіта, інтерактивне навчання, урок математики НУШ, інтерактивний урок математики, освітня стратегія, стратегія “Дерево рішень”, інтерактивна дошка Міго. Проаналізовано вітчизняний та зарубіжний досвід проведення інтерактивного навчання у початковій школі на уроках математики; наведено алгоритм застосування освітньої стратегіі “Дерево рішень” на уроках математики, обтрунтовано необхідність використання нових підходів у процесі навчання математики в початковій школі. Відображено практичні аспекти застосування стратегії “Дерево рішень" на уроках математики в початковій школі, а саме: наведено фрагмент уроку математики в початковій иколі за допомогою освітньої стратегії “Дерево рішень” на інтерактивній дошиі Міго.

Ключові слова: початкова освіта; урок математики НУШ; інтерактивне навчання; інтерактивний урок математики; освітня стратегія; стратегія “Дерево рішень”; інтерактивна дошка Міго.

Puc. 5. Jim. 8.

Nina Rudenko, Ph.D.(Pedagogy), Senior Lecturer of the Primary Education Department, Kyiv Borys Hrinchenko University Yana Huzhyk, Student of the Second (Master's) Educational Level Kyiv Borys Hrinchenko University Denys Shyrokov, Student of the Second (Master's) Educational Level Kyiv Borys Hrinchenko University

\section{THE ORGANIZATIONALAND METHODOLOGICAL BASIS OF THE APPLICATION OF THE EDUCATIONALSTRATEGY "DECISION TREE” IN MATHEMATICS LESSONS IN APRIMARY SCHOOL}

Significant transformations taking place in Ukraine at the beginning of the XXI century concern education as well, in particular primary education. The Ukrainian government is enacting new laws and reform programs for general secondary education until 2029, including the concept of the "New Ukrainian School" (NUS). This reform correlates not only with the best world practices, but also with the needs of the international labor market. It enables students of the new generation to gain knowledge, skills and modern thinking while also promoting European values. The purpose of NUS is to facilitate the transition from the school of knowledge to the school of competencies. Therefore, new methods and approaches to teaching are being introduced. The key task of primary education is not only for the primary school student to accumulate information but also to master the intellectual techniques that are a part of the culture and an integral part of the content of education.

Teaching mathematics is important for primary school since it is a fundamental science that combines general and abstract knowledge. It is used in all fields of knowledge and is a unique means of developing the intellectual potential of the individual, their logical thinking. In this regard, the topical issue of primary school is, on the one hand, high quality teaching of mathematics by a teacher, and on the other hand, high quality studies by students. Taking into consideration the age characteristics of students, it is important to apply interactive technologies in mathematics lessons, in particular the "Decision Tree". It is interactive technologies that play an important role in the learning process, as they stimulate students' cognitive activity and enable its development at all levels (knowledge, understanding, application, assessment) while also maintaining primary students' interest in mathematics.

The following concepts are defined in the article: primary education, interactive learning, NUS mathematics lesson, interactive mathematics lesson, educational strategy, Decision Tree strategy, Miro collaborative whiteboard. The domestic and foreign experience of organizing interactive learning in mathematics lessons in a primary school is analyzed; the algorithm for application of the educational strategy "Decision Tree" in mathematics lessons is given; and the necessity of new approaches in teaching mathematics in a primary school is substantiated. The practical aspects of applying the Decision Tree strategy in mathematics lessons in a primary school are exposed,

(c) Н. Руденко, Я. Гужик,

Д. Широков, 2021 


\section{ОРГАНІЗАЦЙНО-МЕТОДИЧНІ ОСНОВИ ЗАСТОСУВАННЯ ОСВІТНЬОЇ СТРАТЕГЇ “ДЕРЕВО РІШЕНЬ” НА УРОКАХ МАТЕМАТИКИ В ПОЧАТКОВІЙ ШКОЛІ}

namely: a mathematics lesson plan for a primary school with the use of the educational strategy "Decision Tree" on the collaborative whiteboard Miro.

Keywords: primary education; NUS mathematics lesson; interactive learning; interactive mathematics lesson; educational strategy; decision tree strategy; Miro collaborative whiteboard.

П остановка проблеми. Істотні трансформації, які відбуваються в Україні на початку XXI ст., відображаються і в освіті, зокрема початковій. Приймаються нові закони та програми діяльності Уряду України щодо реформування загальної середньої освіти до 2029 р., зокрема концепція “Нової української школи” (НУШ). Ця реформа корелюється не лише з кращими світовими практиками, а й потребами міжнародного ринку праці. Вона формує у школярів нового покоління знання, уміння та сучасне мислення, сприяє утвердженню європейських цінностей. Мета НУШ - перехід від школи знань до школи компетентностей, саме тому впроваджуються нові методи та концепції навчання. Ключовим завданням для початкової освіти є не тільки накопичення учнем початкової школи інформації, а й засвоєння ним інтелектуальних технік, які $є$ складовими культури й невід'ємною частиною змісту освіти.

Для початкової школи важливе значення має викладання курсу математики, оскільки математика $\epsilon$ фундаментальною наукою, яка об'єднує загальне і абстрактне знання, використовується у всіх галузях знань та $\epsilon$ унікальним засобом формування інтелектуального потенціалу особистості, розвитку їі логічного мислення. У зв'язку 3 цим актуальною проблематикою початкової школи, з одного боку, $\epsilon$ якісне викладання вчителем математики, а 3 другого - успішне вивчення учнями цього предмету. Зважаючи на вікові особливості учнів, значної уваги в цьому процесі потребує запровадження інтерактивних технологій на уроках математики, зокрема “Дерево рішень”. Саме інтерактивні технології відіграють важливу роль у процесі навчання, оскільки стимулюють пізнавальну активність учнів та уможливлюють іii розвиток на всіх рівнях (знання, розуміння, застосування, оцінка) та сприяють формуванню у здобувачів початкової освіти стійкого інтересу до математики.

Аналіз останніх досліджень і публікацій. Особлива увага проблемам дослідження початкової освіти приділена багатьма науковцями, зокрема: демократичним та особистісно розвивальним орієнтирам сучасної початкової школи (Н. Бібік, М. Вашуленко, С. Мартиненко, О. Матвієнко, Л. Онищук, О. Савченко); організації та методиці інтерактивного навчання (Л. Карамушка,
О. Комар, Л. Пироженко, О. Пометун, Л. Романенко, Н. Руденко, Г. Сиротенко,); формуванню в учнів наукової та цілісної картини світу (В. Примакова); розв'язуванню дидактико-методичних задач (О. Маляренко); розвитку пізнавальних і творчих інтересів учнів у процесі вивчення математики (С. Бурчак, Л. Ізотова, Н. Руденко); застосуванню педагогічних, в тому числі інтерактивних технологій (Л. Бєкірова, Н. Гордуз, Н. Павленко, Н. Руденко); методиці викладання математики в початковій школі (Л. Коваль, О. Онопрієнко, С. Скворцова); використанню інформаційнокомунікаційних технологій в початковій школі (Т. Мiєр, Н. Морзе, Л. Пєтухова, О. Співаковський). Застосуванню віртуальних дошок та інтерактивних технологій навчання присвячені праці зарубіжних наковців - Д. Каган, А. Кларк, I. Морквян, Г. Рамблє, Дж Хассон, К. Уолш (K. Walsh) та інші.

Виділення невирішених раніше частин загальної проблеми. Процеси глобалізації в освіті вимагають в сучасному світі створення нових підходів до навчання, саме тому спостерігається неймовірно швидкий розвиток інтерактивних технологій та їх упровадження на уроках математики, зокрема - в початковій школі. I, звичайно ж, цей розвиток визначає істотну трансформацію сучасного уроку математики в Новій українській школі, навіть у формі дистанційного навчання в сучасних реаліях, спричинених пандемією COVID-19. Ефективне застосування стратегії “Дерево рішень” на уроках математики в початковій школі формує нові можливості для навчання учнів початкової школи, гартуючи їхні знання та вміння для подальшого навчання.

Мета статті. Головною метою дослідження $€$ обгрунтування педагогічної доцільності й дидактичної цінності застосування освітньої стратегії “Дерево рішень” на уроках математики в початковій школі. Завдання статті - визначити основні дефініції статті: початкова освіта, урок математики НУШ, інтерактивне навчання, інтерактивний урок математики, освітня стратегія, стратегія “Дерево рішень”, інтерактивна дошка Miro; сформулювати алгоритм застосування освітньої стратегії “Дерево рішень” на уроках математики в початковій школі; описати методику застосування інтерактивної дошки Miro, яка дає змогу успішно застосувати стратегію “Дерево рішень" на уроках математики. 
Виклад основного матеріалу. Коротко означимо основні дефініції нашої статті, а саме початкова освіта, урок математики НУШ, інтерактивне навчання, інтерактивний урок математики, освітня стратегія, стратегія “Дерево рішень", інтерактивна дошка Miro.

Початкова освіта - перший ступінь загальної середньої освіти, метою якого у більшості країн світу є одержання дітьми базових умінь і навичок загальнокультурного, загальнорозвивального характеру. Із цією метою в Україні створено Нову українську школу (далі - НУШ) [3].

Інтерактивне навчання - спеціальна форма організації пізнавальної діяльності, яка має конкретну, передбачувану мету - створити комфортні умови навчання, за яких кожен учень відчуває свою успішність, інтелектуальну спроможність $[4,45]$.

Урок математики в НУШ - це форма організації навчання математики 31 по 4 клас, за якої вчитель проводить заняття з групою учнів постійного складу, віком від 6 до 10 років, одного рівня підготовки впродовж одного року відповідно до вибраної навчальним закладом Типової програми Нової української школи (О. Савченко або Р. Шияна) та підручника “Математика”, який відповідає обраній програмі.

Інтерактивний урок математики - урок математики, на якому застосовується сукупність та певна послідовність педагогічних методів, спрямованих на реалізацію дидактичної мети, активізацію суб'єкт-суб'єктної взаємодії учасників освітнього процесу, що впливає на якість математичної підготовки учнів, активізацію їхньої мисленнєвої діяльності $[4,45]$.

Освітня стратегія - (стратегія розвитку освіти) - це концепція, що закладена в основу освітньої політики. Визначає основні напрями i принципи розвитку системи освіти як цілісного соціального інституту.

Дерево ухвалення рішень (дерева класифікацій або регресійні дерева) - використовується у галузі статистики та аналізу даних для прогнозних моделей. Структура дерева містить такі елементи: “листя” і “гілки”. На ребрах (“гілках”) дерева ухвалення рішення записані атрибути, від яких залежить цільова функція, в “листі” записані значення цільової функції, а в інших вузлах атрибути, за якими розрізняються випадки. Щоб класифікувати новий випадок, треба спуститися деревом до листа і видати відповідне значення. Подібні дерева рішень широко використовуються в інтелектуальному аналізі даних [1].

Стратегія “Дерево рішень” - інтерактивна технологія колективно-групового навчання (за класифікацією О. Пометун і Л. Пироженко), яка має передумовою фронтальну, спільну роботу всього класу з розв'язання певної навчальної проблеми. Завдання вчителя - активізація учнів у пошуку способів подолання проблеми. Кожен учень висловлює свою позицію без остраху або побоювань щодо несприйняття його точки зору іншими: сама проблема може містити декілька способів ії розв'язку, кількість наданих учнями пропозицій щодо цього в підсумку обов'язково посприяє її ефективному подоланню [2].

Інтерактивний урок математики в початковій школі потребує ретельної підготовки, адже вчитель має вирішити, яку саме $з$ інтерактивних технологій треба застосувати. Узгодження також вимагають тема та мета уроку, вікові та індивідуальні особливості учнів, ступінь їхньої підготовленості до роботи на уроці.

Використання стратегії “Дерево рішень”, на нашу думку, доцільно проводити в 4 класі початкової школи, адже це допомагає учням оволодіти навичками вибору оптимального варіанту рішення, дії тощо. Побудова “Дерева рішень” є практичним способом оцінити переваги та недоліки різних варіантів. На етапі пропозиції варіантів і на етапі їх оцінки можливе використання також “Мозкового штурму”. Якщо робота проводиться індивідуально або в парах, то учні записують всі можливі рішення проблем або їх наслідки, здатні впливати на подальший хід подій і приводять до певних результатів. Потім викладають їх як “листя”, крони дерева, пояснюючи й хід думок або озвучуючи певний висновок у процесі врегулювання проблемної ситуації.

Відтак для застосування інтерактивної технології “Дерево рішень” на уроках математики вчителю початкових класів необхідно оволодіти знаннями та компетенціями 3 педагогіки, психології, методики викладання математики, зі структури і методики підготовки, організації та проведення інтерактивного уроку математики; розвивати в собі комунікативні здібності, навички зі створення комфортних умов навчання; знати предмет математики, досконало володіти матеріалом уроку, бути ерудованим; опанувати прийоми 3 мотивації учнів до ефективного засвоєння знань для ормуванняння у молодших школярів внутрішньоособистісної зацікавленості у результатах заняття.

Отже, “Дерево рішень”,як освітня технологія сприяє об’єднанню учнів в їхньому прагненні розв'язання загальної задачі. Учасники навчального процесу вчаться грамотно висловлювати свої думки, сприймати інформацію, 


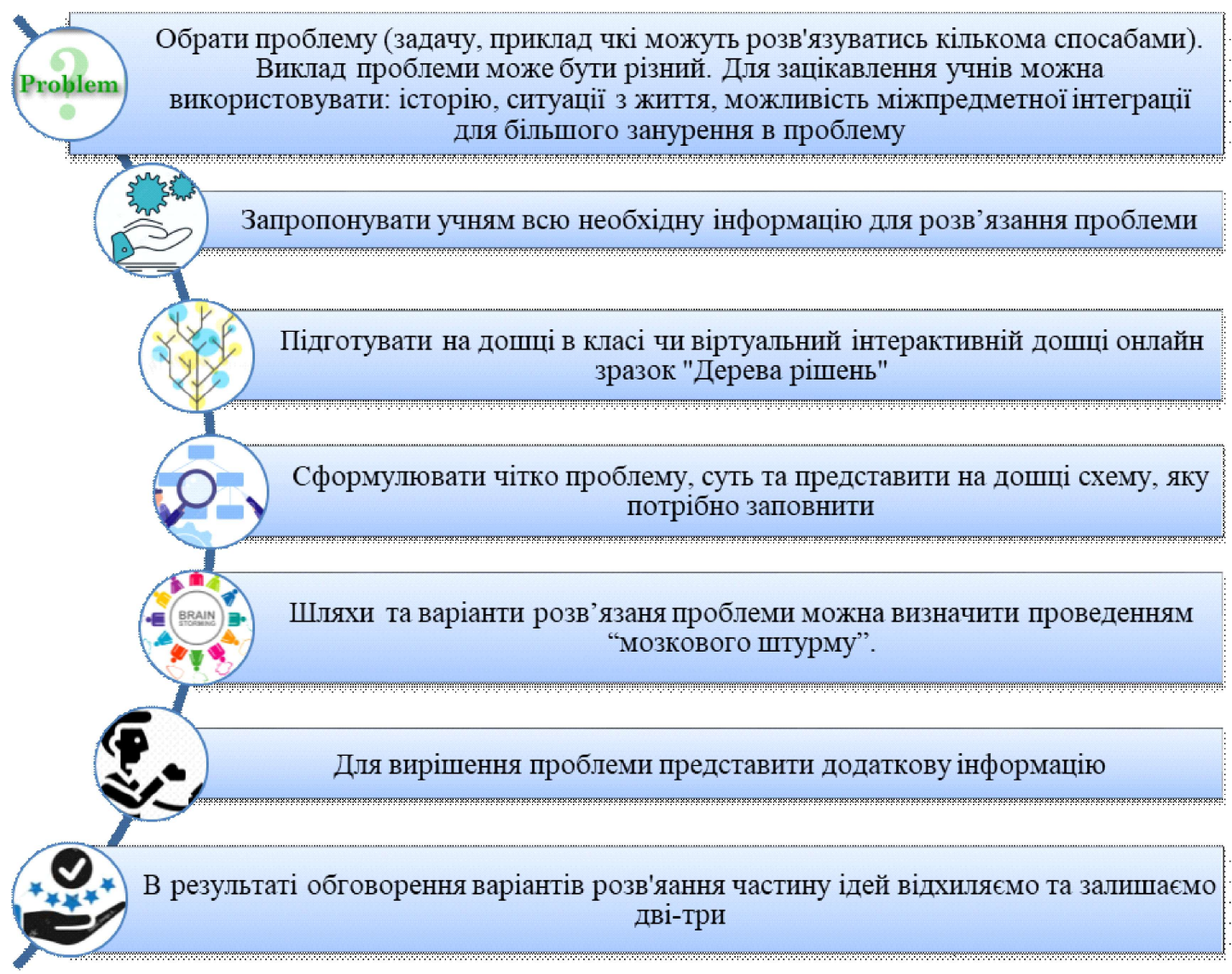

Рис. 1. Алгоритм застосування “Дерева рішень” на уроці математики

\section{[розроблено авторами]}

адекватно реагувати на неї, наводити аргументи та контраргументи, малювати схеми, а також мистецтва діалогу, дискусії.

Стратегія “Дерево рішень” на уроці математики - спосіб розв'язати конкретну проблему [4, 27]. Для організації роботи за допомогою цієї освітньої стратегії пропонуємо такі алгоритм дій (рис 1.).

Такий алгоритм доцільно використовувати й під час дистанційного навчання. Це значно активізує увагу учнів, змушує їх бути зосередженими, адже їм доводиться об'єднуватися в групи для виконання спільного завдання - розв'язання визначеної проблеми.

“Дерево рішень” є алгоритмом діяльності, який допомагає проаналізувати та краще зрозуміти механізми прийняття складних рішень. Вчитель вибирає проблему, яка не має однозначного розв'язку, та надає учням необхідну для розв'язання проблеми інформацію для домашнього опрацювання. Малює на дошці чи роздає кожному дерево рішень. Обговорює кожен iз варіантів подолання проблеми, що є в них позитивного і негативного. У такий спосіб можна відхилити низку ідей і залишити 3-4 найбільш конструктивні. Потім учні діляться на групи для прийняття одного остаточного рішення. Кожна група пропонує своє рішення. Якщо єдності немає, то можна застосувати голосування [4].

Для візуаліації стратегії "Дерево рішень" ефективно використовувати графічне зображення послідовності рішень за допомогою віртуальної дошки Miro.

Інтерактивна дошка Miro ( https://miro.com/ ) - це швидка, безкоштовна та проста у використанні онлайн-дошка, створена для того, щоб допомогти співпрацювати з іншими людьми в будь-який час і в будь-якому місці. $Є$ зручною онлайндошкою для проведення дистанційних групових занять.

За допомогою дошки Miro зручно проводити інтерактивну стратегію “Дерево рішень”, оскільки Miro містить великий вибір шаблонів, швидка та зручна у використанні, має простий та зрозумілий інтерфейс, надає можливість працювати 3 багатьма учасниками у режимі відеозв'язку. Miro пропонує безліч програмних інтеграцій з такими програмами, як JIRA, Trello, Zoom, Slack, 


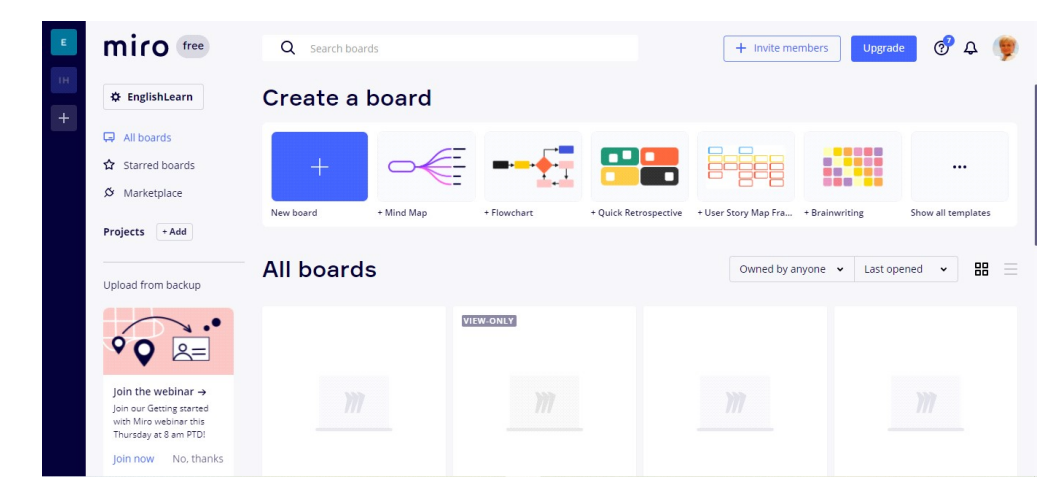

Рис 2. Меню шаблонів побудови схем для завдання “дерево рішень"

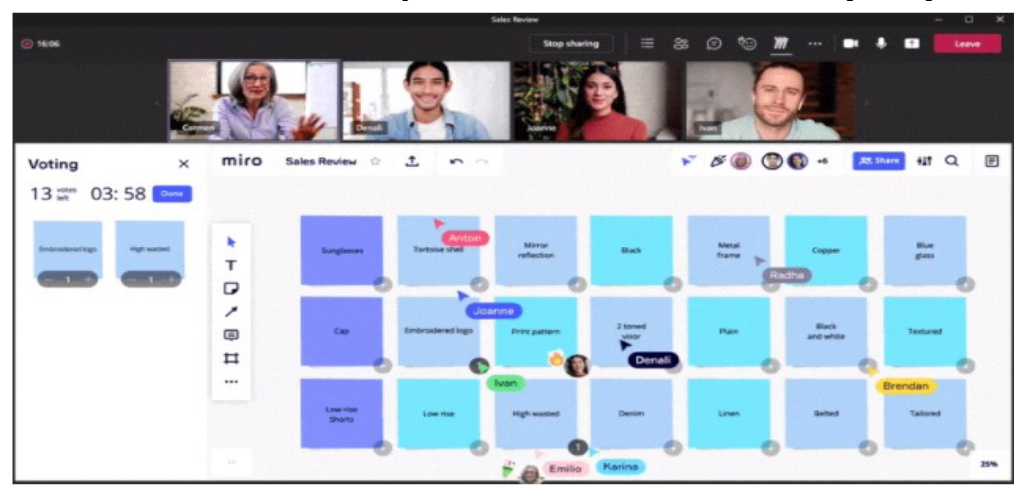

Рис 3. Зразок можливості дистанційного обговорення завдань на платформі Мiro

можливість розміщувати на дошці Міго текст, оцифровані наліпки, рисунки, відео та аудіо файли (рис 2, 3).

Наведемо фрагмент уроку в 4 класі за підручником “Математика 4 клас" (автори С. Скворцова, О. Онопрієнко).

Нами було розроблено “Дерево рішень” для учнів 4 класу з використанням інтерактивної дошки Miro. За проблему ми використали задачу (рис 4.) з підручника “Математика 4 клас” (автори С. Скворцова, О. Онопрієнко ).

На платформі Miro ми змоделювали дерево 3 варіантами розв'язання проблеми (рис 5.)

Представлена задача має два способи розв'язання: 1) частинами; 2) за допомогою рівняння. Учні разом з учителем будують
“Дерево рішень” та знаходять розв'язок. Обговорюють способи розв'язання і вибирають найпростіший спосіб.

Висновки та пропозищії. Використання стратегії “Дерево рішень” $є$ варіантом розв'язання конкретної проблеми. Інтерактивна технологія “Дерево рішень” допомагає здобувачам початкової освіти проаналізувати та краще зрозуміти механізм прийняття складних рішень на уроках математики. Вбачаємо у застосовуванні стратегії “Дерево рішень” можливості для формуванню пізнавального інтересу до вивчення математики в учнів НУШ, розвитку творчого підходу та емоційно-ціннісного ставлення до виконання математичних завдань. Ця освітня стратегія безумовно значно підвищує

\footnotetext{
29 За три дні яхта подолала 24 милі. Другого дня - у 2 рази більше, ніж першого, а третього - у 5 разів більше, ніж першого. Скільки миль долала яхта щодня?
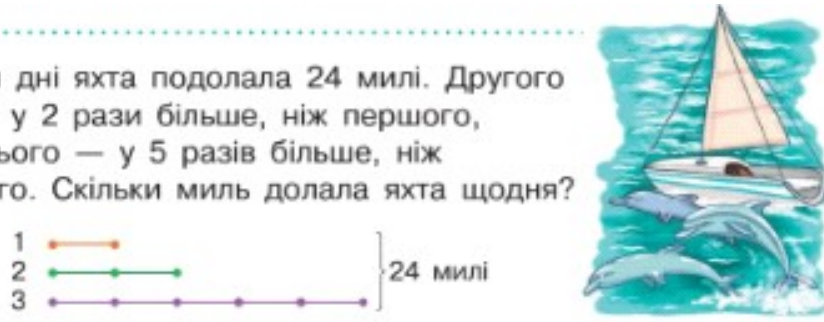

Рис 4. Задача з електронного підручника "Математика 4 клас" (автори С. Скворцова, О. Онопрієнко)
}

46 


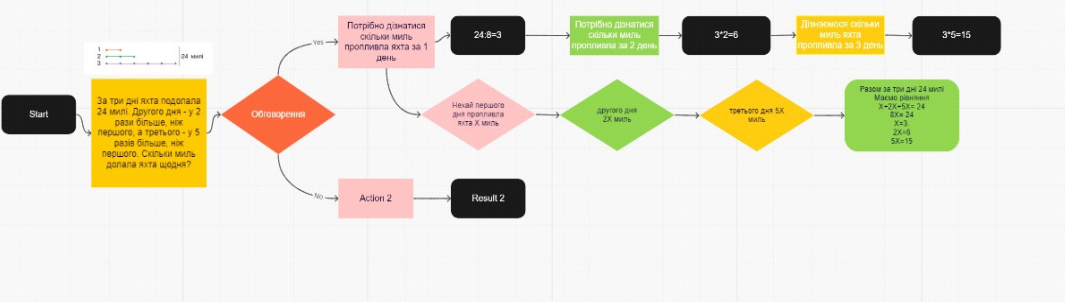

Рис 5. Змодельоване “Дерево рішень” на платформі Miro (https:/cutt.ly/YEanmOz) [розроблено авторами]

ефективність навчального процесу, розкриває здібності кожного учня, забезпечує максимальну ïх активність та підвищує якість навчання.

Потребує дослідження розроблення методичних рекомендацій щодо створення учнями “Дерева рішень” під час роботи над складеними задачами різних видів.

\section{ЛІТЕРАТУРА}

1. Дерево ухвалення рішення (значення). Вікіпедія: вільна енциклопедія. URL: https://cutt.ly/ AEanOjk (дата звернення: 17.09.2021)

2. Пометун О. І. Енциклопедія інтерактивного навчання. Київ, 2007. 144 с.

3. Початкова освіта (значення). Вікіпедія: вільна енциклопедія. URL: https://cutt.ly/PEsF2ox (дата звернення: 17.09.2021)

4. Руденко Н. Інтерактивне навчання на уроках математики в початковій школі. Початкова школа. 2015. № 12. С. 45-48.

5. Руденко Н.М. Застосування е-середовища на уроках математики в початковій школі. Молодий вчений. 2020. №10. С. 435-439.

6. Скворцова С., Онопрієнко О. Методика навчання математики у 3-4 класах закладів загальної середньої освіти на засадах інтегративного і компетентнісного підходів. Київ : Ранок, 2020. 320 c.

7. Скворцова С. Математика: підруч. для 4 кл. закл. загал. серед. осв. Харків: Ранок, 2021. 136 с.

8. Цивенко Я.І. Використання інтерактивних технологій навчання на уроках математики, методичні рекомендації. Маріуполь. 55 с.

\section{REFERENCES}

1. Derevo ukhvalennya rishennya (znachennya)
[Decision tree (value)]. Wikipedia: free encyclopedia. Available at: https://cutt.ly/AEanOjk (Accessed 17 Sept 2021). [in Ukrainian].

2. Pometun, O. (2007). Entsyklopediya interaktyvnoho navchannya [Encyclopedia of interactive learning]. Kyiv, 144 p. [in Ukrainian].

3. Pochatkova osvita (znachennya) [Primary education (value)]. Wikipedia: free encyclopedia. Available at: https://cutt.ly/PEsF2ox (Accessed 17 Sept 2021). [in Ukrainian].

4. Rudenko, N. (2015). Interaktyvne navchannya na urokakh matematyky $\mathrm{v}$ pochatkoviy shkoli [Interactive learning in mathematics lessons in primary school]. Elementary School. No. 12. pp. 45-48. [in Ukrainian].

5. Rudenko, N. (2020). Zastosuvannya eseredovyshcha na urokakh matematyky $\mathrm{v}$ pochatkoviy shkoli [Application of e-environment in mathematics lessons in primary school]. A young scientist. No.10. pp. 435-439. [in Ukrainian].

6. Skvortsova, S. \& Onoprienko, O. (2020). Metodyka navchannya matematyky u 3-4 klasakh zakladiv zahalnoyi serednoyi osvity na zasadakh intehratyvnoho i kompetentnisnoho pidkhodiv [Methods of teaching mathematics in 3-4 grades of general secondary education based on integrative and competence approaches]. Kyiv, 320 p. [in Ukrainian].

7. Skvortsova, S. (2021). Matematyka: pidruch. dlya 4 kl. zakl. zahal. sered. osv. [Mathematics: a textbook for 4 classes of general secondary education]. Kharkiv, 136 p. [in Ukrainian].

8. Tsivenko, Y. Vykorystannya interaktyvnykh tekhnolohiy navchannya na urokakh matematyky, metodychni rekomendatsiyi [The use of interactive learning technologies in mathematics lessons, guidelines]. Mariupol, 55 p. [in Ukrainian].

Стаття надійшла до редакції 25.08.2021

G5808NC2G58080

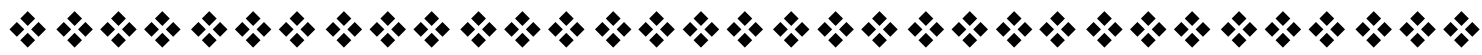

